\title{
Association of Root Caries, Oral Hygiene and Gingival Health Among Adult Population in Baghdad and Mosul City Center (A Comparative Study)
}

Alhan Ahmed Qasim

BDS, MSc (Assist Lect)

\author{
Dept of Pedod, orthod, and Prev Dentistry \\ College of Dentistry, University of Mosul
}

\begin{abstract}
Aims: To determine the association of root caries, oral hygiene and gingival health among adult population in Baghdad and Mosul Cities. Materials and methods: A sample of 210 subjects was selected aged 20 - 60 years, attending the Periodontal Clinic of DentistryCollege at Baghdad and Mosul Universities. For each subject, clinical examination was performed on a dental chair, using plane mouth mirrors and exploratory probe to detect root surface caries. While WHO periodontal probe was used to detect the dental plaque and gingival health. Root Caries Index (RCI) was used for detecting root caries, Plaque Index (PI) for oral hygiene and Gingival Index (GI) for gingival health. T - test was used to find a difference between Baghdad and Mosul, while Duncan's Multiple Range Test was used to find the difference among groups, the differences were considered significant at $p \leq 0.05$. Results: From the total sample the mean Root Caries Index (RCI) rate was (13.69) in Baghdad and (13.59) in Mosul, no significant difference was found between the two cities $(p>0.05)$. The mean Plaque Index (PI) was moderate for Baghdad and Mosul $(1.23,1.04)$ respectively, while Gingival Index (GI) mean was low for both cities $(0.96,0.71)$ respectively. Also subjects who did not brush their teeth revealed a high mean of RCI, PI and GI in both cities than those who brushed their teeth once or more than one time daily with highly significant difference $(p<0.01)$. A significant decrease in the mean of RCI, PI and GI with high level of education $(p \leq 0.05)$ was found. Conclusions: Root surface caries is regarded to be high in both cities population and deserve attention concerning their actual role in the epidemiology of principle oral disease of the adult population.

Key words : Root caries, oral hygiene and gingival health.
\end{abstract}

Qasim A A. Association of root caries, Oral Hygiene and Gingival Health Among Adult Population in Baghdad and Mosul City Center(A comparative study). Al-Rafidain Dent J. 2009; 9(2): 238 -245.

Received: 6/ 5 / $2008 \quad$ Sent to Referees: 6/ 5 / 2008 Accepted for Publication: 6 / 8 / 2008

\section{INTRODUCTION}

Root caries is a soft progressive, lesion that is found anywhere on the root surface that has lost connective tissue attachment and is exposed to the oral environment. Enamel may become secondarily involved if it is undermined during the progression of the lesion. Dental plaque and microbial invasion are essential parts of the cause and progression of this lesion. ${ }^{(1)}$

Root caries has become an important dental problem because people are living longer and keeping their teeth longer. As patients grow older, their gum recede and root surface are exposed, making them more susceptible to root caries. ${ }^{(2)}$

The location of root caries has been positively associated with age and gingival recession. Root caries occur in a location adjacent to the crest of the gingiva where dental plaque accumulate. ${ }^{(2,3)}$

The etiology of root caries is multifactorial. The factors implicated in the development of root caries lesion include dietary habit, microbial plaque and a decreased salivary flow. ${ }^{(4)}$

Root lesions are often very difficult to restore due to their location, problems with moisture control and proximity to the pulp and are therefore prone to high recurrence rates. ${ }^{(5,6)}$

Root caries is generally confined to exposed root surface and is therefore an unusual condition because its occurrence is dependent on previous disease, resulting in a loss of attachment and exposure of cementum. ${ }^{(7)}$

The objectives of this study were to verify the association of root surface caries 
and association oral hygiene and gingival health among adult population of Baghdad and Mosul City.

\section{MATERIALS AND METHODS}

A random sample of 210 subjects were collected with an age range from $20-60$ years old, who were attending the Periodontal Clinic of Dentistry College at Baghdad and Mosul University as a comparative study.

The clinical examination was carried out by one examiner, in a conventional dental chair, with artificial light using a plane mouth mirror and an exploratory probe to detect root caries, while WHO periodontal probe was used to detect dental plaque and gingival health.

The indices used for assessment of dental and gingival condition were as follow:

1.Plaque Index (PI) (Silness and Löe) to evaluate the oral hygiene ${ }^{(8)}$.

2. Gingival Index (GI) (Löe and Silness) to evaluate the gingival health ${ }^{(9)}$.

Root Caries Index (RCI) by Katz: to evaluate the root surface caries ${ }^{(10)}$. The formula of RCI =

$$
\frac{(R-D)+(R-F)}{(R-D)+(R-F)+(R-N)} \quad X 100
$$

Which is defined as:

$(\mathrm{R}-\mathrm{D})$ : root surface with decay and rescission.

$(\mathrm{R}-\mathrm{F})$ : rescission with a filled surface.

$(\mathrm{R}-\mathrm{N})$ : rescission with a sound root surface.

The statistical analysis of data include the following; descriptive statistics including standard statistical method was used to find mean and standard error (SE) of the data. $\mathrm{T}$ - test was used to find a difference between Baghdad and Mosul City center. Duncan's Multiple Range test was used to find the difference among the groups. Multiple regression was used to find a multivariance relationship between the indices and the independent variables.

\section{RESULTS}

The age, gender and side distribution is illustrated in Table (1). The sample was composed of (210) subjects, divided into 4 age groups with 10 years intereval $(20-$ $60)$ years old. In Baghdad the proportion of males was $(28.6 \%)$ and females $(22.9 \%)$, while the proportion of males in Mosul (43.3\%) was much higher than females $(5.23 \%)$. This may related to the traditions of the society in this city.

Table (1): Distribution of studied sample according to site, gender and age.

\begin{tabular}{ccccccccccccc}
\hline & \multicolumn{4}{c}{ Baghdad } & \multicolumn{4}{c}{ Mosul } & \multicolumn{4}{c}{ Total } \\
Age (year) & \multicolumn{3}{c}{ Male } & \multicolumn{2}{c}{ Female } & \multicolumn{3}{c}{ Male } & \multicolumn{2}{c}{ Female } & \multicolumn{3}{c}{ Male } & Female \\
& No. & \% & No. & \% & No. & \% & No. & \% & No. & \% & No. & \% \\
\hline $\mathbf{2 0 - 2 9}$ & 17 & 28.3 & 14 & 29.2 & 35 & 38.5 & 7 & 63.6 & 52 & 34.4 & 21 & 34.8 \\
$\mathbf{3 0 - 3 9}$ & 8 & 13.3 & 16 & 33.3 & 13 & 14.3 & 2 & 18.2 & 21 & 13.9 & 18 & 30.5 \\
$\mathbf{4 0 - 4 9}$ & 6 & 10.0 & 8 & 16.7 & 22 & 24.2 & 0 & 0.0 & 28 & 18.5 & 8 & 13.6 \\
$\mathbf{5 0 - 6 0}$ & 29 & 48.3 & 10 & 20.8 & 21 & 23.1 & 2 & 18.2 & 50 & 33.1 & 12 & 20.3 \\
Total & 60 & 28.6 & 48 & 22.9 & 91 & 43.3 & 11 & 5.23 & 151 & 71.9 & 59 & 28.1 \\
\hline
\end{tabular}

Table (2) shows a significant difference in (RCI), (PI) and (GI) with age (p $\leq 0.05$ ). The mean (RCI) for the total sample in Baghdad was (13.69) and in Mosul (13.59) with no significant difference. Mosul was found to be higher in mean RCI $(10.28)$ in age group $(30-39)$ years compared with Baghdad city (2.59). Mean of
(PI) was found to be moderate in Baghdad (1.23) and Mosul (1.04), while (GI) was low in Baghdad (0.96) and Mosul (0.71). A significant difference between Baghdad and Mosul in plaque and gingival index mean, Baghdad significantly higher than Mosul $(\mathrm{p} \leq 0.05)$. 
Table (2): Mean of root caries, plaque and gingival indices with age between Baghdad and Mosul City.

\begin{tabular}{ccccccccccc}
\hline \multirow{2}{*}{ Index } & Age & \multicolumn{3}{c}{ Baghdad } & \multicolumn{3}{c}{ Mosul } & \multicolumn{3}{c}{ Total } \\
& (year) & Mean & No. & SE & Mean & No. & SE & Mean & No. & SE \\
\hline \multirow{4}{*}{ RCI } & $\mathbf{2 0}-\mathbf{2 9}$ & $5.50 \mathrm{a}$ & 31 & 2.20 & $4.34 \mathrm{a}$ & 42 & 1.89 & $4.83 \mathrm{a}$ & 73 & 1.42 \\
& $\mathbf{3 0}-\mathbf{3 9}$ & $2.59 \mathrm{a}$ & 24 & 0.87 & $10.28^{*} \mathrm{a}$ & 15 & 4.32 & $5.55 \mathrm{a}$ & 39 & 1.82 \\
& $\mathbf{4 0}-\mathbf{4 9}$ & $18.56 \mathrm{~b}$ & 14 & 4.46 & $22.46 \mathrm{~b}$ & 22 & 4.67 & $20.94 \mathrm{~b}$ & 36 & 3.31 \\
& $\mathbf{5 0}-\mathbf{6 0}$ & $25.30 \mathrm{~b}$ & 39 & 3.38 & $24.13 \mathrm{~b}$ & 23 & 4.66 & $24.87 \mathrm{~b}$ & 62 & 2.72 \\
& Total & 13.69 & 108 & 1.77 & 13.59 & 102 & 1.95 & 13.64 & 210 & 1.31 \\
& & & & & & & & & & \\
& $\mathbf{2 0}-\mathbf{2 9}$ & $0.90 \mathrm{a}$ & 31 & 0.08 & $0.64^{* *} \mathrm{a}$ & 42 & 0.06 & $0.75 \mathrm{a}$ & 73 & 0.05 \\
& $\mathbf{3 0}-\mathbf{3 9}$ & $1.21 \mathrm{~b}$ & 24 & 0.11 & $1.01 \mathrm{~b}$ & 15 & 0.13 & $1.13 \mathrm{~b}$ & 39 & 0.08 \\
PI & $\mathbf{4 0}-\mathbf{4 9}$ & $1.31 \mathrm{~b}$ & 14 & 0.12 & $1.50 \mathrm{c}$ & 22 & 0.13 & $1.42 \mathrm{c}$ & 36 & 0.09 \\
& $\mathbf{5 0}-\mathbf{6 0}$ & $1.48 \mathrm{~b}$ & 39 & 0.09 & $0.36 \mathrm{c}$ & 23 & 0.13 & $1.44 \mathrm{c}$ & 62 & 0.07 \\
& $\mathbf{T o t a l}$ & 1.23 & 108 & 0.05 & 1.04 & 102 & 0.06 & 1.14 & 210 & 0.04 \\
& & & & & & & & & & \\
& $\mathbf{2 0}-\mathbf{2 9}$ & $0.57 \mathrm{a}$ & 31 & 0.07 & $0.40^{*} \mathrm{a}$ & 42 & 0.04 & $0.47 \mathrm{a}$ & 73 & 0.04 \\
& $\mathbf{3 0}-\mathbf{3 9}$ & $0.93 \mathrm{~b}$ & 24 & 0.11 & $0.78 \mathrm{~b}$ & 15 & 0.13 & $0.87 \mathrm{~b}$ & 39 & 0.08 \\
GI & $\mathbf{4 0}-\mathbf{4 9}$ & $1.19 \mathrm{~b}$ & 14 & 0.13 & $0.85 \mathrm{bc}$ & 22 & 0.12 & $0.98 \mathrm{bc}$ & 36 & 0.09 \\
& $\mathbf{5 0}-\mathbf{6 0}$ & $1.22 \mathrm{~b}$ & 39 & 0.06 & $1.10 \mathrm{c}$ & 23 & 0.15 & $1.17 \mathrm{c}$ & 62 & 0.08 \\
& Total & 0.96 & 108 & 0.06 & 0.71 & 102 & 0.06 & 0.84 & 210 & 0.54 \\
\hline
\end{tabular}

Means with different letters vertically have significant difference at $p \leq 0.05$ for each index, according to Duncan's multiple range test; * Significant difference between Baghdad and Mosul at $p$ $\leq 0.05$. $* *$ at $p \leq 0.01$, according to $\mathrm{T}$ - test.

No significant difference in mean (RCI) was found between males and females, while males of Mosul showed significantly lower mean plaque and gingival indices $(1.05,0.70)$ respectively than males of Baghdad $(0.99,0.70)$ respectively as shown in Table (3).

Table (3): Mean of root caries, plaque and gingival indices with gender between Baghdad and Mosul City.

\begin{tabular}{ccccccccccc}
\hline \multirow{2}{*}{ Index } & \multirow{2}{*}{ Gender } & \multicolumn{3}{c}{ Baghdad } & \multicolumn{3}{c}{ Mosul } & \multicolumn{3}{c}{ Total } \\
& & Mean & No. & SE & Mean & No. & SE & Mean & No. & SE \\
\hline \multirow{2}{*}{ RCI } & Male & 15.83 & 60 & 2.51 & 13.17 & 91 & 1.97 & 14.23 & 151 & 1.55 \\
& Female & 11.03 & 48 & 2.42 & 17.00 & 11 & 8.17 & 12.14 & 59 & 2.47 \\
& Total & 13.69 & 108 & 1.77 & 13.59 & 102 & 1.95 & 13.64 & 210 & 1.31 \\
& & & & & & & & & & \\
\multirow{4}{*}{ PI } & Male & 1.29 & 60 & 0.07 & $1.05 \S$ & 91 & 0.07 & 1.15 & 151 & 0.05 \\
& Female & 1.15 & 48 & 0.08 & 0.98 & 11 & 0.15 & 1.12 & 59 & 0.07 \\
& Total & 1.23 & 108 & 0.05 & $1.04 \S$ & 102 & 0.06 & 1.14 & 210 & 0.04 \\
& & & & & & & & & & \\
\multirow{2}{*}{ GI } & Male & 0.99 & 60 & 0.08 & $0.70 \S \S$ & 91 & 0.06 & 0.82 & 151 & 0.05 \\
& Female & 0.93 & 48 & 0.08 & 0.76 & 11 & 0.19 & 0.90 & 59 & 0.07 \\
& Total & 0.96 & 108 & 0.06 & $0.71 \S \S$ & 102 & 0.06 & 0.84 & 210 & 0.59 \\
\hline
\end{tabular}

$\S$ Significant difference between Baghdad and Mosul at $p \leq 0.05 ; \S \S$ at $p \leq 0.01$, according to T- test; No.: Numper.

Table (4) and Figure (1) revealed that the subject who did not brushed their teeth showed a higher mean of (RCI) in Bagh- dad (17.57) and Mosul (22.25) than those who did brush their teeth in Baghdad and Mosul $(8.06,5.25)$ respectively. 
Table (4): Mean of root caries, plaque and gingival indices with tooth brushing between Baghdad and Mosul City.

\begin{tabular}{ccccccccccc}
\hline \multirow{2}{*}{ Index } & Tooth & \multicolumn{3}{c}{ Baghdad } & \multicolumn{3}{c}{ Mosul } & \multicolumn{3}{c}{ Total } \\
& brushing & Mean & No. & SE & Mean & No. & SE & Mean & No. & SE \\
\hline \multirow{2}{*}{ RCI } & Yes & 17.57 & 64 & 2.41 & 22.25 & 50 & 3.08 & 19.63 & 114 & 1.92 \\
& No & $8.06 * *$ & 44 & 2.32 & $5.25 * * *$ & 52 & 1.78 & $6.54 * * *$ & 96 & 1.44 \\
& & & & & & & & & & \\
\multirow{2}{*}{ PI } & Yes & 1.46 & 64 & 0.06 & 1.38 & 50 & 0.09 & 1.43 & 114 & 0.05 \\
& No & $0.89^{* * *}$ & 44 & 0.07 & $0.72 * * * \S$ & 52 & 0.06 & $0.80^{* * *}$ & 96 & 0.04 \\
& & & & & & & & & & \\
\multirow{2}{*}{ GI } & Yes & 1.20 & 64 & 0.07 & $0.95 \S$ & 50 & 0.09 & 1.09 & 114 & 0.06 \\
& No & $0.62^{* * *}$ & 44 & 0.07 & $0.48 * * *$ & 52 & 0.05 & $0.54 * * *$ & 96 & 0.04 \\
\hline
\end{tabular}

** Significant difference between brush and no brush at $p \leq 0.01$ and *** $p \leq 0.001 ; \S$ Significant difference between Mosul and Baghdad at $p \leq 0.05$, according to $T$ - test; No.: Numper.

Figure (1): Mean of root caries, plaque and gingival indices with tooth brushing between Baghdad and Mosul City.

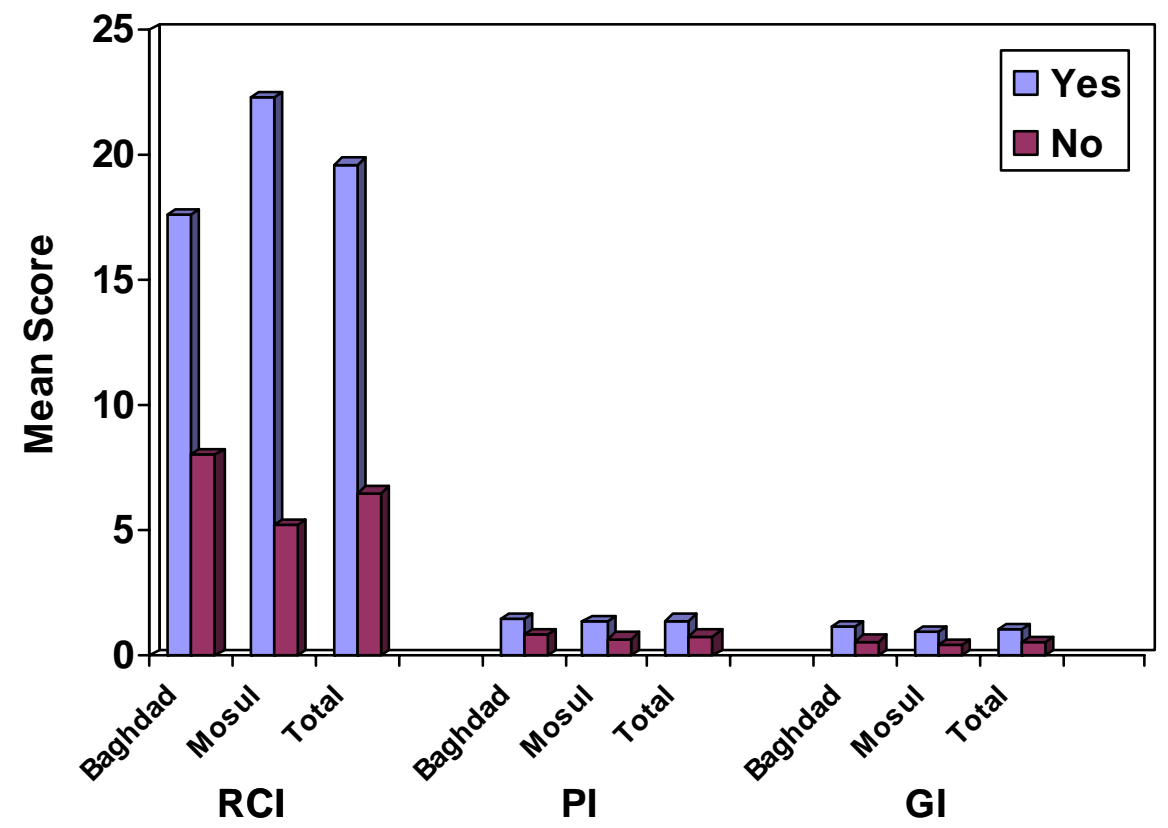

As well as a highly significant difference in the mean of plaque and gingiva between those who did not brush their teeth than others $(p<0.001)$ subjects who brushed their teeth more than one time daily showed lower level of (RCI), (PI) and (GI) in both cities as shown in Table (5). 
Table (5): Frequency of tooth brushing with mean of root caries, plaque and gingival indices between Baghdad and Mosul City.

\begin{tabular}{ccccccccccc}
\hline \multirow{2}{*}{ Index } & \multirow{2}{*}{ Brush / day } & \multicolumn{4}{c}{ Baghdad } & \multicolumn{3}{c}{ Mosul } & \multicolumn{3}{c}{ Total } \\
& & Mean & No. & SE & Mean & No. & SE & Mean & No. & SE \\
\hline \multirow{2}{*}{ RCI } & $\mathbf{1}$ & $14.31 \mathrm{~b}$ & 13 & 5.40 & $5.03 \mathrm{a}$ & 16 & 3.42 & $9.19 \mathrm{a}$ & 29 & 3.13 \\
& $\mathbf{2}$ & $8.02 \mathrm{ab}$ & 21 & 3.28 & $6.01 \mathrm{a}$ & 26 & 2.85 & $6.91 \mathrm{a}$ & 47 & 2.13 \\
& $\mathbf{2}$ & $0.0 \mathrm{a}$ & 10 & 0.0 & $3.64 \mathrm{a}$ & 10 & 1.92 & $1.82 \mathrm{a}$ & 20 & 1.02 \\
& & & & & & & & & & \\
\multirow{2}{*}{ PI } & $\mathbf{1}$ & $1.25 \mathrm{~b}$ & 13 & 0.12 & $0.80^{*} \mathrm{a}$ & 16 & 0.11 & $1.0 \mathrm{~b}$ & 29 & 0.09 \\
& $\mathbf{2}$ & $0.83 \mathrm{a}$ & 21 & 0.08 & $0.62 \mathrm{a}$ & 26 & 0.08 & $0.71 \mathrm{a}$ & 47 & 0.06 \\
& $\mathbf{2}$ & $0.57 \mathrm{a}$ & 10 & 0.08 & 0.82 & 10 & 0.13 & $0.70 \mathrm{a}$ & 20 & 0.08 \\
& & & & & & & & & & \\
\multirow{2}{*}{ GI } & $\mathbf{1}$ & $0.77 \mathrm{a}$ & 13 & 0.11 & $0.62 \mathrm{a}$ & 16 & 0.10 & $0.69 \mathrm{a}$ & 29 & 0.08 \\
& $\mathbf{2}$ & $0.66 \mathrm{ab}$ & 21 & 0.11 & $0.35^{*} \mathrm{a}$ & 26 & 0.06 & $0.49 \mathrm{a}$ & 47 & 0.06 \\
& $>\mathbf{2}$ & $0.34 \mathrm{a}$ & 10 & 0.11 & $0.59 \mathrm{a}$ & 10 & 0.13 & $0.46 \mathrm{a}$ & 20 & 0.08 \\
\hline
\end{tabular}

Means with different letters vertically have significant difference at $p \leq 0.05$ for each index, according to Duncan's multiple range test; * Significant difference between Baghdad and Mosul at $p$ $\leq 0.05$, according to $\mathrm{T}-$ test; No.: Numper.

For level of education Table (6) shows that the mean of (RCI) was found to be higher in low educated level in Mosul (25.60) and Baghdad (16.71) with a significant difference at $(p<0.05)$. A signifi- cant decrease in mean of (PI) and (GI) in both cities with increasing in the level of education $(p<0.05)$. As the highest mean of PI and GI was found in low educational level in both cities

Table (6): Mean of root caries, plaque and gingival indices with level of education between Baghdad and Mosul City.

\begin{tabular}{|c|c|c|c|c|c|c|c|c|c|c|}
\hline \multirow{2}{*}{ Index } & \multirow{2}{*}{$\begin{array}{c}\text { Level of educa- } \\
\text { tion }\end{array}$} & \multicolumn{3}{|c|}{ Baghdad } & \multicolumn{3}{|c|}{ Mosul } & \multicolumn{3}{|c|}{ Total } \\
\hline & & Mean & No. & $\mathrm{SE}$ & Mean & No. & SE & Mean & No. & SE \\
\hline \multirow{4}{*}{ RCI } & Illiterate & $\begin{array}{c}16.71 \\
a\end{array}$ & 66 & 2.20 & $\begin{array}{c}25.60^{*} \\
\mathrm{~b}\end{array}$ & 37 & 3.60 & $19.90 \mathrm{c}$ & 103 & 1.95 \\
\hline & Primary & $\begin{array}{c}17.61 \\
\mathrm{a}\end{array}$ & 13 & 7.07 & $10.58 \mathrm{a}$ & 22 & 4.00 & $\begin{array}{c}13.19 \\
b c\end{array}$ & 35 & 3.62 \\
\hline & Secondary & $5.62 \mathrm{a}$ & 25 & 2.75 & $5.01 \mathrm{a}$ & 38 & 1.96 & $5.25 \mathrm{ab}$ & 63 & 1.60 \\
\hline & College & $1.78 \mathrm{a}$ & 4 & 1.78 & $3.14 \mathrm{a}$ & 5 & 3.14 & $2.53 \mathrm{a}$ & 9 & 1.82 \\
\hline \multirow{4}{*}{ PI } & Illiterate & $1.38 \mathrm{c}$ & 66 & 0.06 & $1.60 * \mathrm{~b}$ & 37 & 0.09 & $1.46 \mathrm{~b}$ & 103 & 0.05 \\
\hline & Primary & $\begin{array}{c}1.24 \\
b c\end{array}$ & 13 & 0.14 & $0.75^{* * \mathrm{a}}$ & 22 & 0.09 & $0.93 \mathrm{a}$ & 35 & 0.08 \\
\hline & Secondary & $\begin{array}{c}0.90 \\
\text { ab }\end{array}$ & 25 & 0.12 & $0.72 \mathrm{a}$ & 38 & 0.06 & $0.79 \mathrm{a}$ & 63 & 0.06 \\
\hline & College & $0.73 \mathrm{a}$ & 4 & 0.21 & $0.60 \mathrm{a}$ & 5 & 0.18 & $0.66 \mathrm{a}$ & 9 & 0.13 \\
\hline \multirow{4}{*}{ GI } & Illiterate & $1.16 \mathrm{~b}$ & 66 & 0.07 & $1.11 \mathrm{~b}$ & 37 & 0.11 & $1.14 \mathrm{~b}$ & 103 & 0.06 \\
\hline & Primary & $\begin{array}{c}0.79 \\
\mathrm{ab}\end{array}$ & 13 & 0.15 & $0.49 * \mathrm{a}$ & 22 & 0.08 & $0.60 \mathrm{a}$ & 35 & 0.08 \\
\hline & Secondary & $0.63 \mathrm{a}$ & 25 & 0.11 & $0.48 \mathrm{a}$ & 38 & 0.05 & $0.54 \mathrm{a}$ & 63 & 0.05 \\
\hline & College & $0.40 \mathrm{a}$ & 4 & 0.13 & $0.50 \mathrm{a}$ & 5 & 0.22 & $0.45 \mathrm{a}$ & 9 & 0.13 \\
\hline
\end{tabular}

Means with different letters vertically have significant difference at $p \leq 0.05$ for each index, according to Duncan $\backslash$ s multiple range test; No.: Numper;* Significant difference between Baghdad and Mosul at $p \leq 0.05$. ** at $p \leq 0.01$, according to $\mathrm{T}-$ test. 
Table (7) shows the finding of multiple regression analysis, relates the prevalence of (RCI), (PI) and (GI) (dependent variables) with other independent variables (age, gender, level of education, teeth brushing). The study revealed that age was highly significantly correlated with prevalence of (RCI), (PI) and (GI), while level of education and teeth brushing are significantly correlated with (PI) only.

Table (7): Multiple regression of root caries, plaque and gingival indices compared independent variables of Baghdad and Mosul City.

\begin{tabular}{cccc}
\hline Index & $\begin{array}{c}\text { Variables } \\
\text { RCI }\end{array}$ & & \\
\cline { 3 - 4 } & $\begin{array}{c}\text { Age } \\
\text { Gender } \\
\text { Education } \\
\text { Brush } \\
\text { Age } \\
\text { PI }\end{array}$ & 0.238 & 0.000 \\
& $\begin{array}{c}\text { Gender } \\
\text { Education } \\
\text { Brush } \\
\text { Age } \\
\text { Gender } \\
\text { Education } \\
\text { Brush }\end{array}$ & & \\
\hline & 0.168 & $<0.001$ \\
\hline
\end{tabular}

Significant difference at $p \leq 0.05$.

\section{DISCUSSION}

Root caries has become an important dental problem, because people are living longer and keeping their teeth longer. Root caries is a common problem among the elderly. It afflicts a large percentage of geriatric patients and is a very difficult problem to manage. The etiology of root caries is multifactorial which may include dietary habits, microbial plaque and decrease salivary flow. ${ }^{(3,11)}$

In general the mean Root Caries Index (RCI) rate obtained in this study was (13.69) in Baghdad and (13.59) in Mosul, with no significant difference between two cities $(p>0.05)$. This result was much higher than that reported by Al-Sayigh ${ }^{(12)}$ in Mosul City (6.34) this could be attributed to the use of various methods for detection of root caries lesion per tooth, per person or number of root caries lesion of teeth present. ${ }^{(13)}$ While it was less than finding of other study (16.3\%) among Brazilian adult. ${ }^{(14)}$ The mean RCI rat was found to be increased significantly with age $(p \leq 0.05)$ for Baghdad and Mosul subjects, as the older subject have been exposed longer time to risk factors, thus root caries has been positively associated with age and gingival recession. ${ }^{(5,15-17)}$

Mean RCI in age group $(30-39)$ years, significantly higher in Mosul subjects than Baghdad $(p<0.05)$. This finding is in agreement with $\mathrm{Al}$-Sayigh. ${ }^{(12)}$

The mean plaque score for the total sample in Baghdad and Mosul was found to be moderate $(1.23,1.04)$ respectively, while the mean gingival score for Baghdad and Mosul was found to be low (0.96, 0.71) respectively. Both indices were found to be significantly higher in Baghdad than Mosul $(p<0.05)$.

The study indicated that the younger age group have healthy gingiva and less dental plaque than older age group, this may be interpreted by the fact that younger group are with a higher awareness concerning dental and oral health education, this is in agreement with the finding of $\mathrm{Al}$ -Sayigh. ${ }^{(12)}$

Concerning gender difference, there was no significant difference between males and females $(p>0.05)$ in mean of $\mathrm{RCI}$, this agree with finding of other researchers ${ }^{(11,12)}$. Both plaque and gingival indices were higher in males compared to 
female in both cities with significant difference $(p \leq 0.05)$; this could be related to the difference in their oral habit and knowledge.

The study revealed that the subjects who did not brush their teeth showed a higher mean percentage of RCI in both Baghdad (17.57) and Mosul (22.25), than those who brushed their teeth, the difference was highly significant $(p<0.01)$. This may be related to the high level of plaque and gingival mean index in those who did not brush their teeth than those who brushed their teeth, because root caries lesion is initiated on a root surface exposed to the oral environment, so a pre requisite for this type of decay (exposure may occur as a result of periodontal disease or vigorous tooth brushing. ${ }^{(18)}$ Also, the subjects in this study who brushed their teeth once or more than one time daily reported lower RCI, PI and GI for Baghdad and Mosul with significant difference $(p<0.05)$ for each index, this agree with the findings of other studies. ${ }^{(12,16,19,20)}$

The mean GI for subjects who brushed their teeth one time daily was higher in Baghdad (0.66) than in Mosul (0.35), this could be related to the high mean of PI (0.83) in those subjects in Baghdad in comparing with the mean PI of others in Mosul (0.62), this agree with findings of other studies. ${ }^{(21,22)}$

Regarding the level of education, in general, the study showed that as the subjects increase in their level of education, the mean of RCI, PI and GI will be decreased, this agree with these findings. 12,16); this may be related to the fact that low educational level subjects neglected their dental health status and this may be revealed to poor oral hygiene, many periodontal problems, lack of dental knowledge and dental health education or may be attributed to insufficient dental services to such people. ${ }^{(16)}$ However, significantly low educational level (illiterate) subjects in Mosul show a high mean of RCI and PI in $(25.60,1.60)$ respectively than Baghdad $(16.71,1.38)$ respectively, this agree with these findings. ${ }^{(12,23,24)}$ This may be attributed to the fact that the exposed root surfaces to oral fluids will lead to accumulation of plaque on these exposed surfaces, leading to bacterial invasion. ${ }^{(25)}$
Findings of multiple regression analysis revealed that there is a significant correlation between age and the mean of RCI, PI and GI, while PI score significantly correlated with the level of education and tooth brushing.

The results of this study showed that the prevalence of root surface caries was accumulative with age as well as PI and GI in both cities (Baghdad and Mosul). So, the best preventive measure against root caries in to maintain periodontal health and avoid apical migration of tissue by improving the oral health status and stimulate the subjects to adapt proper oral hygiene habits and use of different type of fluoride applications.

\section{CONCLUSIONS}

Root surface caries is a major problem in individuals not treated from periodontal disease and in people who have poor oral hygiene. A method of trying to treat this kind of caries by restorative material with poor retention rate of root restorations makes preventive measure mandatory.

\section{REFERENCES}

1. Peter S. Essential of Preventive and community dentistry. Darya Ganj, New Delhi. 2003: 203 - 204.

2. Banting DW. The diagnosis of root caries. J. Dent. Educ. 2001; 65(10): 991 - 996.

3. Banting DW, Ellen RP, Fillery ED. A longitudinal study of root caries: baseline and incidence data. J. Dent. Res. 1985; 64(9): 1141 - 1144.

4. Lynch E, Beighton D. A comparison of primary root caries lesions classified according to colour. Caries Res. 1994; 28(4): $233-239$.

5. Fure S. Five - year incidence of coronal and root caries in 60-, 70- and 80- years old Swedish individuals. Caries Res. 1997; 31: $249-258$.

6. Shaeken MJM, Keltjens HMAM, Vander Hoeven JS. Effects of fluoride and chlorhexidine on the microflora of dental root surface and progression of root surface caries. J. Dent. Res. 1991; 70(2): 150 153.

7. Banting DW, Papas A, Clark DC, Proskin HM, Schultz M, Perry R. The 
8. effectiveness of $10 \%$ chlorhexidine varnish treatment on dental caries incidence in adult with dry mouth. Gerodontology. 2001; 17(2): $2-11$.

9. Silness S, Löe H. Periodontal disease in pregnancy II: correlation between oral hygiene and periodontal condition. Acta. Odontol. Scand. 1964; 22: 121 - 135.

10. Löe H, Silness S. Periodontal disease in pregnancy prevalence and severity. Acta. Odontol. Scand. 1963; 21: 533 - 551.

11. Katz RV. Assessing root caries in population. The evaluation of root caries index. Pub. Health. Dent. 1980; 40(1): 7 - 15.

12. Nordenram G, Bergvit A, Johjson G, Henriksson CO, Anneroth G. Microscopic and radiologic examination of proximal root surface caries. Acta. Odont. Scand. 1988; 46: 95 - 99.

13. Al -Sayigh GD. Prevalence and severity of root surface caries in relation to periodontal status and educational levels in adult population in Mosul City, Iraq. M. Sc. Thesis, College of Dentistry, University of Mosul. 2000.

14. Alerne CA, O'Mullane D, Barrett BE. Indices of root surface caries. J. Dent. Res. 1990; 69(5): 1222 - 1226.

15. Marlivia GW. Root caries prevalence in a group of Brazilian adult dental patient. Braz. Dent. J. 2003; 14(3): 153 - 156.

16. Salman FD, Al -Naimi RJ, Saleh KM. Prevalence and severity of root caries in Qat chewing in Yemen (Thamar). 2004; 1: $197-201$.

17. Fadhi SW. Oral health status and treatment needs among Iraqi factory employee in Baghdad City (a cross sectional study). M. Sc. Thesis. College of Dentistry, University of Baghdad. 1999.
18. Katz R, Hazen S, Chilton N, Mumma R. Prevalence and interoral distribution of root caries in an adult population. Caries Res. 1982; 16: 265 - 271.

19. Macphee T, Cowley G. Essentials of Periogontology and Periodontics, Blackwell Scientific Publication. 1981.P. 305.

20. Vehkalahti M, Paunio LK. Occurrence of root caries in relation to dental health behavior. J. Dent. Res. 1988; 67(6): 911 914.

21. Vehkalahti M. Oral hygiene and root caries occurrence in Slovenian adults. Int. Dent. J. 1997; 47: 26 - 31.

22. Kalsbeek, Tru in GI, Poorterman JHG, Van Rossum GMJ, Van Rokom HM, Verrips GHW. Trends in periodontal status and oral hygiene habits in Dutch adults between 1983 and 1995. Comm. Dent. Oral Epid. 28: 112 - 118.

23. Khamrco TY. Epidemiological study on prevalence of plaque and gingivitis among adolescents and adult population $(15-54)$ years in Hamam-Allel villages, Ninevah, Iraq. Al - Rafidain Dent. J. 2001; 1: 283 290.

24. Schamschula RG, Barn's DE, Keyes PH, Gulbinat W. Prevalence and interrelationship of root caries in Iufa, Papua New Guinea. Comm. Dent. Oral Epid. 1974; 2: $295-304$.

25. Avald N, Birkhed D, Hamp SE. Root caries susceptibility in periodontally treated patient. Result after 12 years. $J$. Clin. Period. 1993; 20: 124 - 129.

26. Winn DM, Brunelle JA, Selwitz RH, Kaste LM, Oldakowski RJ, Kingman A, Brown LJ. Coronal root caries in the dentition of adults in the United Status. 1988 1991. J. Dent. Res. 1996; 75: 642 - 651. 